\title{
Developing augmented reality in mathematics learning: The challenges and strategies
}

\author{
Muhamad Ikhsan Sahal Guntur ${ }^{1}$ *, Wahyu Setyaningrum ${ }^{1}$, Heri Retnawati ${ }^{1}$, Marsigit \\ Marsigit ${ }^{1}$, Novilda Angela Saragih ${ }^{1}$, Muhamad Kahir bin Noordin ${ }^{2}$ \\ ${ }^{1}$ Universitas Negeri Yogyakarta. Jalan Colombo No. 1, Karangmalang, Yogyakarta 55281, Indonesia. \\ ${ }^{2}$ Universiti Teknologi Malaysia. Jalan Iman, 81310 Skudai, Johor, Malaysia. \\ E-mail: ikhsan.guntur@gmail.com \\ * Corresponding Author
}

\begin{tabular}{|c|c|}
\hline ARTICLE INFO & ABSTRACT \\
\hline $\begin{array}{l}\text { Article history } \\
\text { Received: } 29 \text { Nov. 2019; } \\
\text { Revised: } 26 \text { Dec. 2019; } \\
\text { Accepted: } 2 \text { January } 2020 \\
\text { Keywords } \\
\text { augmented reality, } \\
\text { challenges; strategy }\end{array}$ & $\begin{array}{l}\text { One of the technologies developed massively in learning is Augmented Reality } \\
\text { (AR) technology. This research will explain the challenges of teachers in } \\
\text { developing AR-assisted learning media and strategies to anticipate the } \\
\text { challenges that arise in developing AR-assisted learning media. This type of } \\
\text { research is qualitative phenomenological research. The participants of this } \\
\text { research were } 75 \text { Mathematics teachers who joined the developing AR-assisted } \\
\text { learning media training. The teachers came from various regions in Indonesia. } \\
\text { The mathematics teachers invited were } 36 \text { junior high school teachers and } 29 \\
\text { senior high school teachers from public and private schools who were } \\
\text { vulnerable at the age of } 22-35 \text { years and } 27 \text { teacher is male and the others are } \\
\text { female. They have attended an AR-assisted media development training } \\
\text { because have interested in AR and education. The data collection used is a } \\
\text { questionnaire and an interview which is done to all participants and data } \\
\text { analyzed using the Bogdan \& Biklen model. The results of the research show } \\
\text { that the challenges encountered by the teacher are meeting the minimum } \\
\text { standards of hardware and software, limited references both sourced from } \\
\text { humans, online media or print media. Efforts made by teachers to overcome } \\
\text { existing problems such as gradually upgrading laptops, finding sources from } \\
\text { foreign languages and trying to form joint learning communities. }\end{array}$ \\
\hline
\end{tabular}

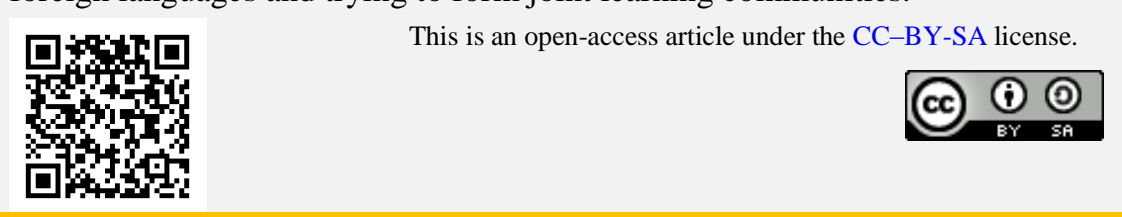

How to Cite: Guntur, M., Setyaningrum, W., Retnawati, H., Marsigit, M., Saragih, N., \& Noordin, M. (2019). Developing augmented reality in mathematics learning: The challenges and strategies. Jurnal Riset Pendidikan Matematika, 6(2), 211-221. doi:https://doi.org/10.21831/jrpm.v6i2.28454

\section{INTRODUCTION}

Today's technological developments affect various aspects of human life. Starting from the way they communicate, look for relationships or even find information. In the world of education itself, technology has begun to be used to support teaching and learning or evaluation of learning. For example, the Indonesian government uses computer-based tests instead of paper-based tests that are considered more effective and efficient in national examinations (Retnawati et al., 2017). Technology-based learning or e-learning is also starting to be used in Indonesia. For example, the teacher starts using android-based games to support student learning in class (Ardani \& Setyaningrum, 2018; Pratama \& Setyaningrum, 2018). Mathematics teacher's awareness in using media as a teaching tool has also increased (Wijayanti et al., 2018). But the problem is technology-based media that uses to teach mathematics like this are still limited in Indonesia (Guntur et al., 2015; Mahnun, 2012). The second problem is that of 177.9 million smartphone users in Indonesia, the biggest contributor comes from the age category of children and adolescents, which unfortunately is still not wise in its use (Zaini \& Soenarto, 
Jurnal Riset Pendidikan Matematika, 6 (2), 2019 - 212

Muhamad Ikhsan Sahal Guntur, Wahyu Setyaningrum, Heri Retnawati, Marsigit Marsigit, Novilda Angela Saragih, Muhamad Kahir bin Noordin

2019). Of course, a wise way to overcome this problem is not to prohibit children from using smartphones but how to optimize the use of smartphones in the world of education.

Augmented Reality (AR) technology is the merging of two-dimensional or three-dimensional virtual objects into a real-world environment and then projecting these virtual objects in real-time (Azuma et al., 2001). The application of AR in learning began to be used in various learning subjects such as mathematics, chemistry, biology, and many more where the use of AR is incorporated into books (Lee, 2012). Liao et al. (2015) explain that AR has 3 functions including Cubic Nets, Three-Dimensional View, and Spatial Cube. Some of the advantages possessed by AR in learning in class include being able to use learning content in the form of three dimensions, enabling independent learning, enabling to improve the ability of the five senses, visualizing objects that are difficult to be seen by the naked eye, and finally being able to bridge formal and informal learning (Wu et al., 2013).

The development of AR in the world of education itself from year to year is increasingly massive and will continue in the years to come (Wu et al., 2013). The obstacle of teachers in developing AR in learning is difficult to develop especially for teachers who do not have basic technology (Chang et al., 2014), takes a long time to develop (Gavish et al., 2015), the program used produces large files that are difficult to share or run on low-specification smartphones (Ke \& Hsu, 2015), not suitable when used in group-based learning that is too large (Yoon et al., 2012).

But if we read some research that looks at the impact of using AR in the learning process (e.g. Dunleavy et al., 2009), using AR can improve critical thinking, problem solving, and communicating. Karagozlu (2018) in his research concluded that AR can improve problem solving skills and student learning outcomes. On the other hand, the research conducted Liao et al. (2015) concludes AR can improve students' spatial abilities so it is not excessive if we conclude that AR has various positive impacts on learning. This conclusion is also strengthened by opinion Nincarean et al. (2013) which explains that AR has enormous potential in education so that it will be able to assist the learning process.

In its development in the classroom, of course, the teacher is the right person to develop AR in accordance with the conditions and typical students. Of course, it will be very interesting to see how the challenges of teachers developing AR-based media and the solutions made by these teachers. In this study, the differentiator than other studies is the subject under study is the mathematics teacher in Indonesia who actually took the AR program making training from scratch then looked at the challenges and strategies undertaken by this teacher and finally saw whether with all the existing obstacles the teacher will still develop and use AR in the past and how the general description of this technology will be used by him in the classroom.

Based on the background of the problems and literature review related to the use of AR, it can be understood that $\mathrm{AR}$ can be used as an alternative to increasing student motivation and learning achievement, including in learning mathematics. But the development of AR in learning mathematics is not easy, especially for teachers in Indonesia. Therefore, this research aims to describe the challenges of teachers in developing AR-assisted learning media and to describe the teachers' strategy in anticipating the challenges that arise in developing AR-assisted learning media.

\section{METHOD}

This research was conducted by using qualitative phenomenological design. The phenomena described in this research were the challenges confronted by the teachers in developing the AR-assisted learning media, the strategy used by the teacher to overcome the problems in developing the AR-assisted learning media.

This research was conducted in September 2019, in which the training of AR-assisted learning media development was held within ten days at Universitas Negeri Yogyakarta (Yogyakarta State University, Indonesia). Three days of training is conducted face-to-face and one week is given the task of independently making a simple program. The training program invites AR experts from Jakarta who have their own studio and focus on developing AR in the fields of education, marketing, science and engineering. The training was focused on introducing how to develop AR programs, starting from installing support programs on laptops to installing them on participants' smartphones. The interview was carried out after the training completed.

The data were obtained by questionnaire and interviewing all of the participants. Prior to the interview, the researcher disseminated a questionnaire that aims at figuring out the initial overview 
related to the research objectives. The interview was used to probe into the interviewees' respond towards the issue and to confirm their response in the questionnaire. The questions in the interview focused on what challenges teachers confronted in developing the AR-assisted learning media and the strategy that the teachers used to solve the problems.

The participants of this research were 75 Mathematics teachers who joined the developing ARassisted learning media training. The teachers came from various regions in Indonesia. The mathematics teachers invited were 36 junior high school teachers and 29 senior high school teachers from public and private schools who were vulnerable at the age of 22-35 years and 27 teacher is male and the others are female. They were invited because they have an interest in developing AR in mathematics education.

The data analyses consist of some steps: interview data transcription, data reduction, and data analysis. The data analysis was done by using Bogdan dan Biklen (1982) model. It aims at determining the inter-theme relations and gain a more detail understanding. The data analysis result obtained was used to comprehend the constraints and strategies undertaken by the participants regarding the ARassisted learning media development.

\section{RESULT AND DISCUSSION}

\section{Result}

Learning material development, especially in mathematics has some challenges. Challenges of developing AR to develop AR-assisted learning material, the teacher should have adequate hardware and software so as the development process can run well. In fact, most of the teachers were constrained to meet the hardware and software minimum standard which is needed in the development process. The challenges found will be presented in Table 1 .

Table 1. The Challenges to Meet the Hardware and Software Minimum Standard.

\begin{tabular}{|c|c|c|}
\hline Challenges & Theme & Inter-Theme Relation \\
\hline $\begin{array}{l}\text { The laptop processor used is the old series. } \\
\text { The laptop RAM used is } 2 \text { GB on average. } \\
\text { The Windows used is } 32 \text { bit. } \\
\text { The laptop is fully installed with other programs. } \\
\text { Too many programs installed. } \\
\text { The unavailability of older versions of the program. } \\
\text { They do not have a laptop. } \\
\text { The price of the compatible laptop is too expensive. }\end{array}$ & $\begin{array}{l}\text { The laptop specifications } \\
\text { used are not compatible. } \\
\text { There are too many } \\
\text { programs installed and } \\
\text { need more space. } \\
\text { The inability to have a } \\
\text { compatible laptop. }\end{array}$ & $\begin{array}{l}\text { The difficulty } \\
\text { confronted regarding } \\
\text { meet the hardware } \\
\text { and software } \\
\text { minimum standard. }\end{array}$ \\
\hline
\end{tabular}

The first problem encountered is the way teachers meet the hardware and software minimum standard used. According to Table 1, the problems are present in three categories. The first category is related to the specifications of the laptop used. Some interview excerpts are as follows.

S59: "kondisi laptop yang kurang mendukung karena menggunakan processor yang lama, seharusnya bisa di upgrade terlebih dahulu sebelum mengembangkan AR" [laptop conditions that are less supportive because it uses an old processor, should be able to be upgraded first before developing AR].

S69: "Spesifikasi laptop yang masih kurang, karena laptop yang saya pakai RAM-nya hanya 2GB, sepertinya RAM perlu di upgrade" [Laptop specifications are still lacking, because my laptop only has 2 GB of RAM capacity, it looks like RAM needs to be upgraded].

S28: "Saya kesulitan menginstal aplikasi blender, karena laptop saya windows-nya masih 32 bit. Belum 64 bit dan RAM saya masih 2 GB" [I have trouble installing the blender application, because my laptop has 32-bit windows, not yet 64 bits and my RAM is still 2 GB].

The fact is there are four applications that will be installed on the developer's laptop: Unity, Blender, Android studio, and Vuforia. There are three specifications for the unity program, i.e.: (a) The OS required is minimal Windows 7,8,8.1 and windows 10 which is only available for 64-bit version or macOS 10.12+, (b) CPU: SSE2 instruction set support, (c) GPU: Graphics card with DX10 (shader model 4.0) capabilities (Unity3d, 2019). 
The second problem is there are too many programs installed and more free space is required on the developer's laptop. As aforementioned that there are four applications should be installed in the developer's laptop: Unity, Blender, Android studio, dan Vuforia. All the programs used much RAM and ROM memory. In addition, the older software is unavailable in which it might consume less memory space and more compatible with the older series laptop. Some interview excerpts are as follows.

S13: "Laptop saya slow respon karena terlalu banyak program yang harus di instal" [My laptop is slow response because there are too many programs to install].

S11: "Laptop saya mempunyai ruang yang sedikit, jadi loadingnya terlalu lama, mungkin karena sudah banyak program yang diinstall di dalamnya" [My laptop has little space, so loading is too long maybe because there are already many programs installed on it].

S22: "iya, seharusnya ada versi yang lebih lawas yang bisa saya pakai karena laptop saya sangat jadul, karena biasanya kalau versi lawas akan lebih ringan" [yes, there should be an older version that I can use because my laptop is very old, because usually if the older version will be lighter].

The third problem is the teachers' inability to buy the laptop as the price is higher compared to their monthly income, especially for the contract or honorary teachers. It can be concluded that the difficulty confronted related to meeting the hardware and software standard consists of the low laptop specifications, the number of the installed programs, and the inability to purchase the compatible laptop. Some interview excerpts are as follows.

S50: "Laptop saya tidak kompatibel, kalau mau beli harganya sepertinya mahal, terlebih saya belum jadi PNS dan hanya guru honor" [My laptop isn't compatible, if I want to buy it seems expensive, especially since I haven't become a civil servant and only an honorarium teacher].

S59: "Saya tidak punya laptop, jadi ketika belajar menggembangkan AR saya menggunakan laptop teman saya yang mengakibatkan hasilnya kurang maksimal" [I don't have a laptop, so when I learned to develop AR using my friend's laptop that resulted in less than maximum results].

The next challenges is how to using the installed program because most of the teacher is the first time to develope some kind of this program. The challenges found will be presented in Table 2 .

Table 2. The Challenges of Using the Installed Programs.

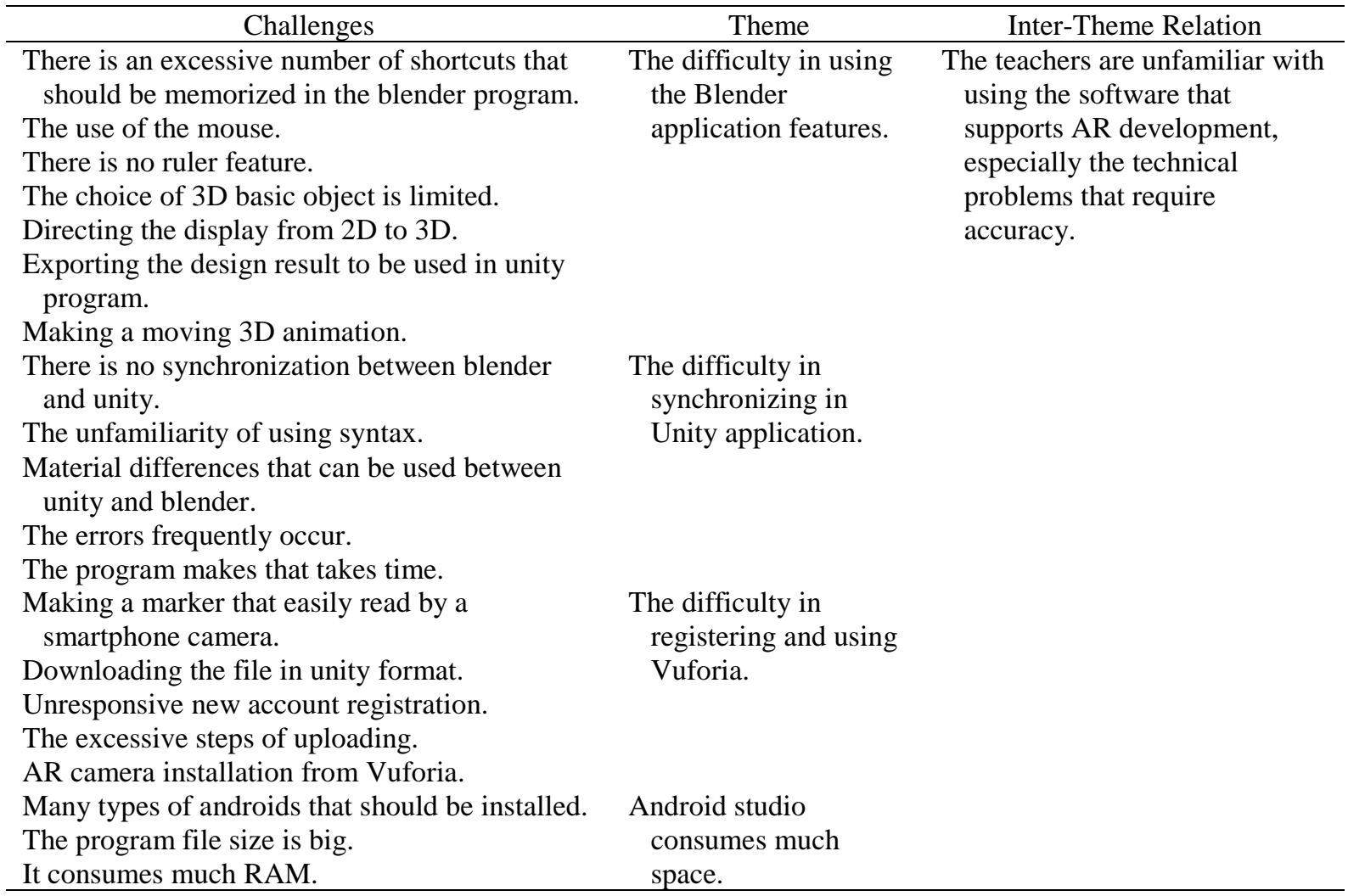


Jurnal Riset Pendidikan Matematika, 6 (2), 2019 - 215

Muhamad Ikhsan Sahal Guntur, Wahyu Setyaningrum, Heri Retnawati, Marsigit Marsigit, Novilda Angela Saragih, Muhamad Kahir bin Noordin

As has been aforementioned that there are four main programs in the use of AR; Blender, Unity, Android studio, and Vuforia. Each program has its own challenges in its use. Blender program has an excessive number of shortcuts that should be memorized, especially for the old series. According to Katsbits.com, there are more than 400 shortcuts that are useful in Blender (Katsbits, 2014), for instance; Alt + P for Poker Face, As most of the shortcuts should be memorized, the teachers find it difficult to run the program. Further, the teachers also confronted some problems related to comprehending the 3D pictures as they are unfamiliar with $3 \mathrm{~d}$ pictures in $2 \mathrm{D}$.

The main problem is caused by the low spatial skill of the teachers. Unavailability of ruler feature in blender program also causes difficulty for the teachers to make a similar width and height of the objects. The limited options of 3D basic objects also become one of the problems for the teachers in making a new object. For example, there is no prism shape in the blender program. There is the only cube. This urges the teachers to create prism by combining the cubes as the sides of the prism. After finishing with the $3 \mathrm{D}$ object, the next problem coming is creating the animation object's movement. The teachers are unfamiliar with adobe flash, resulting in their inability to create the animation's movement.

The animation movement in the blender program requires the teachers to understand the cerebration or algorithm of the blender program. For instance, to make a cone that pours water to a tube. The teacher should understand that the cone movement is not merely up and down, but the transferring process of water to the tube should be shown. Moreover, the teachers also should pay attention to how to export the design so that it can be used in Unity program as the teachers' product in the training is frequently unable to be used in the Unity program. It happens since the teachers forget to checklist certain items and set the object gauge prior to installing. Some interview excerpts are as follows.

S68: "Saya kesulitan di program Blender, mungkin karena belum ada pengetahuan sebelumnya tentang ini, namun karena tools yang banyak membuat saya sedikit bingung" [I have difficulty in the Blender program, maybe because there is no prior knowledge about this, but because of the many tools that make me a little confused].

S5: "kesulitan saya pada Blender, tools-tools yang masih banyak membingungkan" [My difficulty is with Blender, tools that are still a lot of confusion].

The second problem is the difficulty of running the Unity program. It is caused by the unavailability of direct synchronizing between Blender and Unity. When the teacher is coloring an object in Blender, he should make sure that the object also exists in Unity so that when it is transferred, it will have similarly emerged. This also prevails on the other features. Blender application is needed in AR development as the unity program is limited in terms of giving animation on $3 \mathrm{D}$ objects. Moreover, the use of syntax also became a problem for the teachers as they do not get used to using a computer. They only copy-paste the syntaxes that were given in training. Unity program is frequently errors in their laptop resulting in a panic situation in the training rooms. The application of the unity program takes much time if there are a considerable number of script or the programming language. It happens since those codes should be further analyzed (Gavish et al., 2015). Some interview excerpts are as follows.

S7: "Saat mengikuti langkah-langkah yang diberikan tersebut, namun gambar tidak muncul sama sekali pada layar serta setelah dicoba dengan keluar dan membuka kembali program tetap saja belum bisa. Saya pun kesulitan dalam menggabungkan file yang sudah saya simpan di program blender dengan program unity" [When following the steps given, but the picture does not appear at all on the screen and after trying to exit and reopen the program still can not. I also had difficulty in combining files that I have saved in the blender program with the unity program]

S34: "Iya, pada program Unity karena stepnya cukup banyak kemudian sintaks-sintaks yang digunakan tidak hanya dengan copy paste tapi harus dianalisis juga" [Yes, in the Unity program because there are quite a lot of steps then the syntax is used not only by copy and paste but must also be analyzed].

The third problem is the application of the Vuforia program. Maker making is the most important part of this application. However, to make a maker that is easily read by the camera and gets good ratings is hard to do as the Vuforia website does not provide any instruction on how to make a good maker. This causes teachers to do trials and errors while looking for the best results. In some cases, teachers confronted some difficulties in downloading Vuforia files in Unity format. Sometimes, the downloaded 
files are in HTML format which cannot be converted into Unity. Further, account registrations are also not responsive. Most teachers did not receive notifications through email which make them must register many times. The most confusing problem is when some of the teachers' laptop is an error while downloading and installing AR camera from Vuforia even though the steps done are completed. They should re-install the program to be a success. Some interview excerpts are as follows.

S34:" Iya ketika login ke Vuforia, susah untuk loginnya padahal alamat email dan user namenya sudah benar. File yang didownload juga tidak berformat semestinya, pas di buka tidak bisa" [Yes, when logging into Vuforia, it's hard to log in even though the email address and username are correct. The downloaded file is also not formatted properly, right when it can't open].

From all the problems, the application of the Android studio program is the program that absorbs much memory space (RAM). As Indonesia has many Android types, the teachers must download all the programs to be able to use them in all smartphones. If the smartphone is IOS-based, the memory needed is larger. Some interview excerpts are as follows.

S27: "karena jenis Android sangat banyak, jadi harus banyak sekali program yang harus saya download supaya program saya bisa kompetible ketika dipakai oleh siswa" [because there are so many types of Android so there must be a lot of programs that I have to download so that my program can be compatible when used by students].

The next challenge is to look for references on the use of AR development programs. The challenges found will be presented in Table 3 .

Table 3. The Challenge is to Look for References on the Use of AR Development Programs

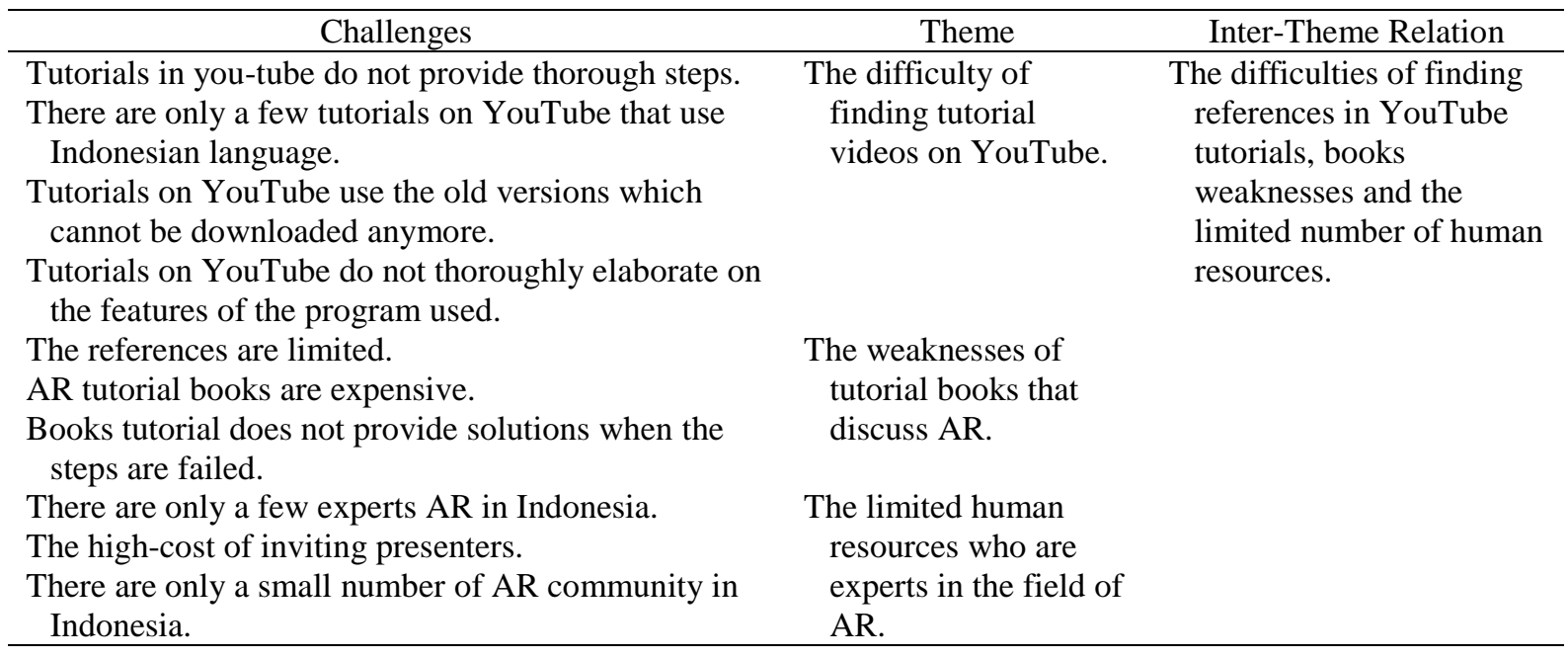

A large number of references that are used must have assisted the developer in AR development. In fact, based on the interview conducted, the interviewees confront some difficulties in looking for references. Their difficulty in finding the references is divided into three categories, based on the reference source.

The first is YouTube. It does not provide a detailed step. The youtubers sometimes conceal the detail steps in the hope that the viewers will purchase for the full version of it. The instructional language also becomes the problem as the tutorials on YouTube are not delivered in Bahasa. Then the teachers only pay attention to what the youtubers does without being able to comprehend what those features, in AR development application, are useful for. This results in the inability of the teachers to create another program. In addition, some of the tutorials use the old version which cannot be downloaded and this causes confusion to the teachers as the display between their program and the tutorial's program are not similar. Some interview excerpts are as follows.

S08: "Sangat sulit mencari referensi belajar baik dari youtube atau pun website, kalau pun ada mereka pakai bahasa Inggris jadi saya pusing" [It is very difficult to find study materials from YouTube or websites, even if they use English, I feel dizzy]. 
Jurnal Riset Pendidikan Matematika, 6 (2), 2019 - 217

Muhamad Ikhsan Sahal Guntur, Wahyu Setyaningrum, Heri Retnawati, Marsigit Marsigit, Novilda Angela Saragih, Muhamad Kahir bin Noordin

S45: "Masalahnya adalah ketika para youtuber membuat pelatihan pembuatan program di youtube, step-step yang ada suka di skip dan kalau mau yang full biasanya disuruh beli CD atau buku yang mereka buat" [the problem is when the youtubers make a training program on YouTube, the steps that are available are skip and if you want the full one, you are usually told to buy discs or books that they make]

The next is the problem of taking in the tutorial in books. It does not provide a solution for the teachers when one of the steps come to standstill, and there is no explanation about this. The limited number of reference books, which are expensive, demotivates the teacher to seek for other references from other books. These reasons urge them to look for other references.

The last is that the teachers will be more excited to learn directly from the expert as it will hinder misconception. However, the limitations of the human resources, who are excel in AR, and the AR community in Indonesia complicate the students to learn more. Further, some experts set a high rate of price to be paid, so the teachers are reluctant to invite them except in pieces of training.

After we discuss some of the obstacles experienced by the teachers, the next stage is how the teachers overcome this. The strategies found will be presented in Table 4.

Table 4. Strategies for Overcoming the Challenges

\begin{tabular}{|c|c|c|}
\hline Strategies & Theme & Inter-Theme Relation \\
\hline Upgrading the laptop's RAM & \multirow[t]{3}{*}{ Upgrading the laptop } & \multirow{8}{*}{$\begin{array}{l}\text { The solution can be } \\
\text { started from the } \\
\text { renewal of hardware, } \\
\text { increasing the } \\
\text { number of references, } \\
\text { and improving human } \\
\text { resources. }\end{array}$} \\
\hline Replacing the hard-drive to SSD & & \\
\hline Purchasing for a new laptop & & \\
\hline Looking for tutorials on YouTube. & Increasing the number & \\
\hline $\begin{array}{l}\text { Looking for another program that is easier to be learned. } \\
\text { Looking for appropriate tutorial books. }\end{array}$ & of references & \\
\hline Getting used to the practice & Improving human & \\
\hline Creating an AR community & resources & \\
\hline Joining an advanced AR training & & \\
\hline
\end{tabular}

The computers or laptops limitation used by the developers can be overcome by buying a new laptop that complies with the minimum specifications of the required program. Indeed, not all teachers are able to do that. Therefore, an alternative solution that can be done by teachers is to upgrade their laptop RAM with affordable price or to replace the laptop hard-drive, formed in the hard disk drive (HDD), to Solid State Drive (SSD) which has 10 times faster than on HDD in general. Some interview excerpts are as follows.

S50: "Meng-upgrade laptop yang sudah ada dengan mengganti komponen yang dirasa masih bisa di upgrade dengan tidak memakan banyak dana" [Upgrading an existing laptop by replacing components that are still felt could be upgraded by not consuming much funds]

Related to the limited references, the solution that can be done by the teacher is to look for English books or video tutorial and language experts to translate the steps that are not understood by the teachers. Another step is to look for other alternative programs that might have more references. Some interview excerpts are as follows.

S63: "lebih banyak membaca dan melihat berbagai referensi tentang penggunaan AR, lebih banyak latihan untuk memahami fungsi-fungsi menu, tools yang ada di AR." [read more and see various references about the use of AR, more practice to understand menu functions and tools in AR]

To improve human resources, there should be a long-term solution. There are some ways that can be done to overcome this issue: (1) the teachers will try to get themselves used to practice independently; (2) they create an AR community where the teachers share information and obstacles they experience, expecting that there will be a solution obtained; (3) the teachers will have an active role to join AR trainings held by the other parties. Some interview excerpts are as follows.

S55: "Belajar lagi, lagi dan lagi sampai bisa dan selalu mencoba" [Study again, again and again until I can and always try].

S58: "Lebih banyak membuat komunitas belajar antar sesama" [Make more community learning between people]. 
Jurnal Riset Pendidikan Matematika, 6 (2), 2019 - 218

Muhamad Ikhsan Sahal Guntur, Wahyu Setyaningrum, Heri Retnawati, Marsigit Marsigit, Novilda Angela Saragih, Muhamad Kahir bin Noordin

S65: "ikut pelatihan yang dilakukan pihak yang lain" [participate in training conducted by other parties].

\section{Discussion}

The development of technology in the educational area encourages teachers to innovate in classroom learning. One of the technologies that are close to students is a smartphone. According to Setyaningrum and Waryanto (2018), the use of smartphones in classroom learning increases students' motivation and learning outcomes. Discussing the suitable programs to be developed in a smartphone, $\mathrm{AR}$ is the answer. This can be seen from the increasing number of AR-assisted research in smartphones for education (Akçayır \& Akçayır, 2017).

Regardless of the increasing number of AR development in smartphones for education, it turns out that in the process of the development, there are some problems confronted by the teachers in terms of meeting the minimum standard of software and hardware needed because the high cost of laptops or computers that must be used. This is in accordance with research conducted by Furió et al. (2013) which explains the high costs required in developing AR. The next challenge is the difficulty in using the application that has been installed. This result is very consistent with research conducted by Chiang et al. (2014) which explains that AR programs making it difficult to develop for a large number of the software used to the complexity of its use. Not to mention the bugs applied that cause the application error is in accordance with the results of research conducted by Phon et al. (2014) which explains that errors that occur in the use of AR applications cause excessive stress to the teacher. Moreover, the technical problems can occur on-camera use, bad internet connections, and the difficult programming languages Y.-L. Chang et al. (2015). The length of time for the development process also becomes an obstacle. This is consistent with the results of research Gavish et al. (2015) which implies a similar thing.

The most fundamental challenge of all is the teachers' limited knowledge and ability of IT (Retnawati et al., 2017). Moreover, the trainings is rare to be held so that it does not reach all teachers and it causes them not to be able to implement the new knowledge related to the process of learning and the use of technology (Retnawati, Munadi, et al., 2017), to create learning floe of HLT (Retnawati, 2017), and it also affects the teacher in designing the application of AR in the classroom. The limitations of reference to learn how to develop media such as AR are very limited and ultimately make it difficult for teachers (Guntur et al., 2015).

Although the development of AR in the current situation faces many challenges, both academics and industry believe that there is a huge potential possessed by AR, especially in the educational field (Yu et al., 2009). For instance, AR can be used as an additional learning tool for students. This will enable teachers and students to be accustomed to using technology and allow more research to be developed (Thornton et al., 2012). Based on the results of interviews with all teachers who participated in AR development training, most of them agreed to apply AR in classroom learning as it would help teachers to improve students' affective and cognitive abilities. This statement is also supported by Coimbra et al. (2015) who explained that "augmented reality can encourage motivation, comprehension and a higher involvement with the contents to be learned. Thus, it may increase the use of information and access to knowledge, improve digital and info-inclusion".

The potential use of AR can also be done to teach mathematics in other subjects, where the teachers confronted difficulties in teaching physics in which mathematics is used as a basis Retnawati et al. (2018). Further, they also argue that the teachers also find it difficult to teach thematic at the elementary school level and require technology or media that are suitable as the solution (Retnawati, 2017).

\section{CONCLUSIONS}

This research concludes that there are many challenges that are passed, especially if the developer is a teacher who does not have the ability to create a computer program in advance. Based on the interviews with all teachers who took part in the training, it was found that their challenge in developing AR was the difficulty of meeting the minimum hardware and software standards because the specifications of their laptops were still low. The teachers are also not accustomed to using supporting software to develop AR, especially for technical problems that require precision and accuracy. So, there was a moment of panic when their program closed itself or didn't work as it should be. 
The limited references that can be accessed also become a challenge for teachers. The teachers have difficulty in finding the learning references either from books, the internet, or learning from experts directly. However, some of these obstacles can be overcome or anticipated by the teachers through several efforts, such as gradually upgrading a laptop, trying to find other language references, and trying to form learning communities. The teachers in other countries who want to develop AR can understand the challenges that will arise in this research, so the teachers can develop a suitable strategy so that in the development AR does not find significant obstacles. Future learning potentials can be an input for other researchers to develop AR in other materials. In addition, based on this research, training for teachers to develop and use AR in Indonesia are needed.

\section{REFERENCES}

Akçayır, M., \& Akçayır, G. (2017). Advantages and challenges associated with augmented reality for education: A systematic review of the literature. Educational Research Review, 20, 1-11. https://doi.org/10.1016/j.edurev.2016.11.002

Ardani, R. A., \& Setyaningrum, W. (2018). Game-based edutainment media using guided discovery approach: What teachers say. Journal of Physics: Conference Series PAPER. https://doi.org/10.1088/1742-6596/1097/1/012101

Azuma, R., Baillot, Y., Behringer, R., Feiner, S., Julier, S., \& MacIntyre, B. (2001). Recent advances in augmented reality. IEEE Computer Graphics and Applications, 21(6), 34-47. https://doi.org/10.1109/38.963459

Bogdan, R. C., \& Biklen, S. K. (1982). Qualitative research for education: An introduction to theory and methods. MA: Allyn and Bacon.

Chang, K.-E., Chang, C.-T., Hou, H.-T., Sung, Y.-T., Chao, H.-L., \& Lee, C.-M. (2014). Development and behavioral pattern analysis of a mobile guide system with augmented reality for painting appreciation instruction in an art museum. Computers \& Education, 71, 185-197. https://doi.org/10.1016/j.compedu.2013.09.022

Chang, Y.-L., Hou, H.-T., Pan, C.-Y., Sung, Y.-T., \& Chang, K.-E. (2015). Apply an augmented reality in a mobile guidance to increase sense of place for heritage places. Journal of Educational Technology \& Society, 18(2), 166-178. https://www.learntechlib.org/p/158888/

Chiang, T. H. C., Yang, S. J. H., \& Hwang, G. J. (2014). Students' online interactive patterns in augmented reality-based inquiry activities. Computers and Education, 78, 97-108. https://doi.org/10.1016/j.compedu.2014.05.006

Coimbra, M. T., Cardoso, T., \& Mateus, A. (2015). Augmented reality: An enhancer for higher education students in math's learning? Procedia Computer Science, 67(Dsai), 332-339. https://doi.org/10.1016/j.procs.2015.09.277

Dunleavy, M., Dede, C., \& Mitchell, R. (2009). Affordances and limitations of immersive participatory augmented reality simulations for teaching and learning. Journal of Science Education and Technology, 18(1), 7-22. https://doi.org/10.1007/s10956-008-9119-1

Furió, D., González-Gancedo, S., Juan, M.-C., Seguí, I., \& Costa, M. (2013). The effects of the size and weight of a mobile device on an educational game. Computers \& Education, 64(May 2013), 24-41. https://doi.org/10.1016/j.compedu.2012.12.015

Gavish, N., Gutiérrez, T., Webel, S., Rodríguez, J., Peveri, M., Bockholt, U., \& Tecchia, F. (2015). Evaluating virtual reality and augmented reality training for industrial maintenance and assembly tasks. Interactive Learning Environments, 23(6), 778-798. https://doi.org/10.1080/10494820.2013.815221

Guntur, M. I. S., Hiltrimartin, C., \& Indaryanti, I. (2015). Persepsi guru matematika SMA di kayuagung terhadap kurikulum 2013. Jurnal Pendidikan Matematika, 9(1), 68-77. https://doi.org/10.22342/jpm.9.1.2134.68 - 77

Karagozlu, D. (2018). Determination of the impact of augmented reality application on the success and 
Jurnal Riset Pendidikan Matematika, 6 (2), 2019 - 220

Muhamad Ikhsan Sahal Guntur, Wahyu Setyaningrum, Heri Retnawati, Marsigit Marsigit, Novilda Angela Saragih, Muhamad Kahir bin Noordin

problem-solving skills of students. Quality \& Quantity, 52(5), 2393-2402.

https://doi.org/10.1007/s11135-017-0674-5

Katsbits. (2014). Shortcuts (hotkey) \& charts for blender. KatsBits. http://www.katsbits.com/tutorials/blender/useful-keyboard-shortcuts.php

Ke, F., \& Hsu, Y.-C. (2015). Mobile augmented-reality artifact creation as a component of mobile computer-supported collaborative learning. The Internet and Higher Education, 26, 33-41. https://doi.org/10.1016/j.iheduc.2015.04.003

Lee, K. (2012). Augmented reality in education and training. TechTrends, 56(2), 13-21. https://doi.org/10.1007/s11528-012-0559-3

Liao, Y.-T., Yu, C.-H., \& Wu, C.-C. (2015). Learning geometry with augmented reality to enhance spatial ability. 2015 International Conference on Learning and Teaching in Computing and Engineering, 221-222. https://doi.org/10.1109/LaTiCE.2015.40

Mahnun, N. (2012). Media pembelajaran (Kajian terhadap langkah-langkah pemilihan media dan implementasinya dalam pembelajaran). An-Nida', 37(1), 27-35. http://ejournal.uinsuska.ac.id/index.php/Anida/article/view/310

Nincarean, D., Alia, M. B., Halim, N. D. A., \& Rahman, M. H. A. (2013). Mobile augmented reality: The potential for education. Procedia - Social and Behavioral Sciences, 103, 657-664. https://doi.org/10.1016/j.sbspro.2013.10.385

Phon, D. N. E., Ali, M. B., \& Halim, N. D. A. (2014). Collaborative augmented reality in education: A review. 2014 International Conference on Teaching and Learning in Computing and Engineering, 78-83. https://doi.org/10.1109/LaTiCE.2014.23

Pratama, L. D., \& Setyaningrum, W. (2018). Game-based learning: The effects on student cognitive and affective aspects. Journal of Physics: Conference Series, 1097, 012123. https://doi.org/10.1088/1742-6596/1097/1/012123

Retnawati, H. (2017). Learning trajectory of item response theory course using multiple softwares. Olympiads in Informatics, 11, 123-142. https://doi.org/10.15388/ioi.2017.10

Retnawati, H., Arlinwibowo, J., Wulandari, N., \& Pradani, R. (2018). Teachers' difficulties and strategies in physics teaching and learning that applying mathematics. Journal of Baltic Science Education, 17(1), 120-135. http://www.scientiasocialis.lt/jbse/?q=node/643

Retnawati, H., Hadi, S., Nugraha, A. C., Arlinwibowo, J., Sulistyaningsih, E., Djidu, H., Apino, E., \& Iryanti, H. D. (2017). Implementing the computer-based national examination in Indonesian schools: The challenges and strategies. Problems of Education in the 21st Century, 75(6), 612 633.

Retnawati, H., Kartowagiran, B., Arlinwibowo, J., \& Sulistyaningsih, E. (2017). Why are the mathematics national examination items difficult and what is teachers' strategy to overcome it? International Journal of Instruction, 10(3), 257-276. https://doi.org/10.12973/iji.2017.10317a

Retnawati, H., Munadi, S., Arlinwibowo, J., Wulandari, N., \& Sulistyaningsih, E. (2017). Teachers' difficulties in implementing thematic teaching and learning in elementary schools. The New Educational Review, 48(2), 201-212. https://doi.org/10.15804/tner.2017.48.2.16

Setyaningrum, W., \& Waryanto, N. H. (2018). Developing mathematics edutainment media for Android based on students' understanding and interest: a teachers' review. Journal of Physics: Conference Series, 983(1), 012093. https://doi.org/10.1088/1742-6596/983/1/012093

Thornton, T., Ernst, J. V., \& Clark, A. C. (2012). Augmented reality as a visual and spatial learning tool in technology education. Technology and Engineering Teacher, 71(8), 18-22.

Wijayanti, R., Hasan, B., \& Loganathan, R. K. (2018). Media comic math berbasis whiteboard annimation dalam pelajaran matematika. Jurnal Riset Pendidikan Matematika, 5(1), 53. https://doi.org/10.21831/jrpm.v5i1.19207 
Jurnal Riset Pendidikan Matematika, 6 (2), 2019 - 221

Muhamad Ikhsan Sahal Guntur, Wahyu Setyaningrum, Heri Retnawati, Marsigit Marsigit, Novilda Angela Saragih, Muhamad Kahir bin Noordin

Wu, H.-K., Lee, S. W.-Y., Chang, H.-Y., \& Liang, J.-C. (2013). Current status, opportunities and challenges of augmented reality in education. Computers \& Education, 62, 41-49. https://doi.org/10.1016/j.compedu.2012.10.024

Yoon, S. A., Elinich, K., Wang, J., Steinmeier, C., \& Tucker, S. (2012). Using augmented reality and knowledge-building scaffolds to improve learning in a science museum. International Journal of Computer-Supported Collaborative Learning, 7(4), 519-541. https://doi.org/10.1007/s11412012-9156-x

Yu, D., Jin, J. S., Luo, S., Lai, W., \& Huang, Q. (2009). A useful visualization technique: A literature review for augmented reality and its application, limitation \& future direction. In M. L. Huang, Q. V. Nguyen, \& K. Zhang (Eds.), Visual Information Communication (pp. 311-337). Springer US. https://doi.org/10.1007/978-1-4419-0312-9_21

Zaini, M., \& Soenarto, S. (2019). Persepsi orangtua terhadap hadirnya era teknologi digital di kalangan anak usia dini. Jurnal Obsesi : Jurnal Pendidikan Anak Usia Dini, 3(1), 254. https://doi.org/10.31004/obsesi.v3i1.127 